clear weapons than a number of other countries that might obtain them. The Chinese tests have proved unsettling in Asia; but the addition of other Asian nations to a select nuclear club would only exacerbate not calm the situation.

It has been argued that the spread of nuclear weapons in other parts of the world-Asia is only one example-would actually be beneficial to the United States. It would, this argument runs, establish a balance of power and would allow the United States to curtail some of its commitments, commitments that are already straining U.S. resources. The arguments opposing this are, however, more plausible. The United States cannot presently withdraw from the various commitments that are hers. And if this could be made a feasible policy in the near future it would remain unlikely that the United States could refrain totally from an Asian nuclear conflict.

Few people see even the possibility of withdrawing present commitments from Europe and no one argues seriously for such a proposal. What does exist is widespread agreement that multilateral measures designed to stop the spread of nuclear capabilities are obviously complicated and vexing. Consider only the role of Germany, The Soviet Union continually announces her fears of and her objection to the possibility that Germany might gain some control of nuclear weapons, and part of the political problem is to assess the sincerity of Soviet fears. But the Soviet Union is not the only country that would not regard an independent German nuclear force with equanimity. It would not be so regarded' by the United States, Britain, France, and by a great number of Germans.

Still, West Germany must and will look to its own interests. The multilateral nuclear force (MLF) and the Atlantic nuclear force (ANF) were designed to give Germany participation in but not control of nuclear systems. For a number of reasons, including Russia's proclaimed fear that Germany would play too significant a role, these plans have been shelved at least for the time.

Still lively is a tough proposal by Franz Josef Strauss, a former defense minister of West Germany, for a European nuclear force that would be autonomous, free of U.S. control. The United States has newly proposed a "select cominittee" of defense secretaries that would, hopefully, strengthen NATO, counter de Gaulle's recent di- visive actions, and encourage the Soviet Union to negotiate realistically on a number of helpful multilateral proposals that would inhibit the spread of nuclear weapons.

Whether anything actually comes from these proposals or the prolonged discussions that have accompanied each of them will depend upon what each country thinks it has to gain or lose by any single proposal, but looming large in these considerations is the Soviet Union's estimate of whether a non-proliferation agreement is worth the sacrifice of some effective political propaganda.

But while such an assessment would solve one set of problems it would give new life to others. In the face of the increased Soviet-U.S. cooperation demanded by any of the recommended plans, the problems of holding NATO together would mount: Nor would the Soviet Union find her role among the Communist countries of the world more comfortable. The world could, possibly, become a less orderly place than it is now.

The problems of controlling the spread of nuclear weapons are urgent and complicated. The only consolation is the bitter observation that they can be urgent problems only for a limited number of years.

\section{THE SWEET AND THE BITTER}

We continue to insist on the intimate relation that exists between domestic policy and foreign policy, but there are only occasional issues which reveal that relation with clarity. The Sugar Act is one of those issues.

Representative Cooley and his House Agriculture Committee have amended the existing Sugar Act and extended it for an additional five years. At a cost to the American consumer of $\$ 700 \mathrm{mil}$ lion annually, the existing Act is burden enough. But the amendments to this act were engineered in flagrant disregard for any interests but those of the lobbyists and the pockets they sweeten. Argentina, having refused to engage a lobbyist, had its annual quota of sugar cut by two-thirds; Venezuela, apparently wiser in the ways of Washington, hired a lobbyist and had its quota increased almost eight-fold. Lobbying for Venezuela, Charles Patrick Clark gets $\$ 125,000$, cost passed on to the American citizen. This is not business as usual; the practice of having foreign countries Iobby such bills through Congress has nothing to recommend it to the voter. J.F.

2 tworldview 